\title{
THE EFFECT OF DISINFECTION OF EXTENDED-POUR ALGINATE IMPRESSIONS ON THE SURFACE ROUGHNESS OF STONE CASTS
}

\author{
Iman M.S.Matar
}

\begin{abstract}
The study aimed to estimate the influence of disinfection of impression material (Hydrogum 5 extended-Pour alginates) on the surface roughness of the resulting casts. Materials and Methods: In this study, 40 alginate impressions using Hydrogum 5 extended-Pour alginates. The impressions were divided into four groups according to different time of storage and pouring intervals: one, six, 12 and 24 hours. Each time interval has ten impressions which were divided into two groups (control and study) each group has five impressions which stored in sealed plastic bags then casting with dental stone. In control groups the impressions stored without disinfection and in study groups the impressions were sprayed with (AHD 2000) ready-made commercial disinfectant material then stored. Surface roughness test was measured for every specimen by (Mahr) Marsurf PS1Data analysis were done by Student $\mathrm{T}$ - test and ANOVA $(\mathrm{P}<0.05)$.Results: Extended-Pour alginates not significantly affected the surface roughness of the stone casts either with or without disinfection. Conclusion: This study demonstrated that casting may be postpone up to 24 hours using Hydrogum 5 extended-Pour alginates. likewise pouring after disinfectant.
\end{abstract}

KEY WORDS: Disinfection, Extended-Pour alginate, Surface roughness Impression Materials;

\section{INTRODUCTION}

Irreversible hydrocolloid (alginate) is an impression material routinely used in dentistry because of its acceptable accuracy, reasonable price,availability, and easily handling ${ }^{(1)}$. As well as, it is commonly used for preliminary impressions to obtain a study cast used for treatment planning, diagnostic purposes, construction of custom trays or provisional prostheses ${ }^{(2)}$. Dental impression is considered as a remarkable way for transmission of microorganisms like hepatitis B,tuberculosis or AIDS from the office to other environments because of its contact with saliva and blood during the impression procedure ${ }^{(3,4)}$.

Undoubtedly microorganisms from the contaminated impressions can be also transmitted to stone models ${ }^{(5)}$. To prevent cross-infection, American Dental Association (ADA) and the Centers for Disease Control recommended the decontamination of dental impressions before

\footnotetext{
* Lecturer, Department of Prosthodontics, Faculty of Dentistry, Pharos University, Alexandria, Egypt
} 
being poured with gypsum which considered as a routine clinical process in dental laboratories and clinics ${ }^{(6,7,8)}$.

The researchers in the literature vary markedly in their selection of disinfectant types, concentration and procedure. There are many commercially available disinfectant solutions that have been recommended to disinfect dental impressions such as aqueous solutions of alcohols, phenolics, aldehydes, chlorhexidine gluconate, povidone-iodine, glutaraldehyde, and sodium hypochlorite ${ }^{(9,10)}$.

Alcohols are used by dentists as the most popular chemical disinfectants ${ }^{(11)}$. Irreversible hydrocolloid impressions keep microorganisms at a level that is 2 to 3 times higher than other impressions due to their hydrophilic and organic composition, which help the growth of microorganisms so they prevent the process of disinfection ${ }^{(12)}$.

Spraying is the common way for disinfection because it minimize or eliminate undesirable effects that immersion of alginate would cause and accordingly to the stone casts. Therefore, ill-fitting prosthesis is fabricated that causes pain and discomfort to the patient ${ }^{(13)}$. Disinfectants of the irreversible hydrocolloids impressions and the storage period before casting are critical factors in the dimensional accuracy of the impressions as well as the resulting casts ${ }^{(14,15)}$.

Irreversible hydrocolloid impressions undergoes syneresis or imbibition when exposed to the air or water which can affect its dimensional stability, leading to less accurate casts. Therefore, pouring of the conventional alginate immediately or after short time, maximally within 12 minutes of removal from the mouth is recommended to prevent distortion ${ }^{(16,17)}$.

If immediate pouring alginate impressions is not possible or dentists have no time for pouring by themselves and they sent it to the dental laboratories for poring and casts making., it is advocate that the impressions should be preserved in an environment with $100 \%$ comparative humidity to keep the water balance inside the material ${ }^{(18)}$.

In many cases, the delay in pouring the impressions extended than the advocated time which will cause dimensional changes in the impressions ${ }^{(19)}$. Recently, the producers of a new irreversible hydrocolloid (extended-pour) claimed that it can be increased its pouring time, up to five days and maintaining its dimensional accuracy during these periods. ${ }^{20,21)}$.

Different researches have been made to analyze dimensional accuracy of the models casted from these materials after different pouring intervals, but only few studies done on the influence of these materials with and without disinfection on the surface roughness of the gypsum models ${ }^{(18,22)}$. Disinfection of the impressions specially irreversible hydrocolloid should eliminate the pathogens without causes changes in surface details of the casts, which can affect fit or retention the prosthesis ${ }^{(23)}$, but it is not clear in the literature the influence of disinfectants on these new materials, (extended-pour alginate impressions) The objective of this research was to assess the effect of disinfection on the surface roughness of stone casts gained from irreversible hydrocolloid (extended-pour) at different periods of pouring \& storage (one, six, 12 and 24 hours) compared with casts of impressions that were not disinfected.

\section{MATERIALS \& METHODS:}

in the present study, 40 extended-pour alginate impressions using Hydrogum 5 (5 days dimentional stability) (Zhermack, Badia Polesine, Italy) were made using especially metallic mold prepared for testing the casts as regard the surface roughness.

The impressions were divided into four intervals of storage \& pouring time: one, six, 12, and 24 hours. Each time interval has ten impressions were then divided into two groups. Each group has five impressions: (control group) poured to form stone casts without disinfection. 
(Study groups) poured following spraying with ready-made commercial disinfectant material: AHD 2000 (Alcohol-based disinfectant), (Medicare international co. Hong Kong) Preparation of dental models: Hydrogum 5 extended-Pour alginates. was mixed as claimed by the manufacturer's instructions. The mixed impression material was filled into a metallic mold (figure 1) then, the impressions covered and pressed slowly by glass slab to extrude the excess material., without incorporation of air between the impression and the glass slab ${ }^{(24)}$. The material was allowed to set, for the time advocate by the manufacturer. After setting, the impressions were preserve in humid environment in sealed plastic bags to simulate conditions in which the impressions were generally kept before transfer to the dental laboratory. ${ }^{(20,24)}$ At the end of time intervals, the impressions of the test groups were rinsed for 60 seconds under tap water to remove any traces of the disinfectant solution. The impressions of both groups were poured with dental stone which was mixed manually for 45 seconds and thereafter vibrated for 30 seconds. The mixed stone was poured onto the impression's surfaces mounted in the metallic mold and held in place until setting at room temperature.

After one hour of stone pouring, the disc-shaped stone specimen were separated from the impression

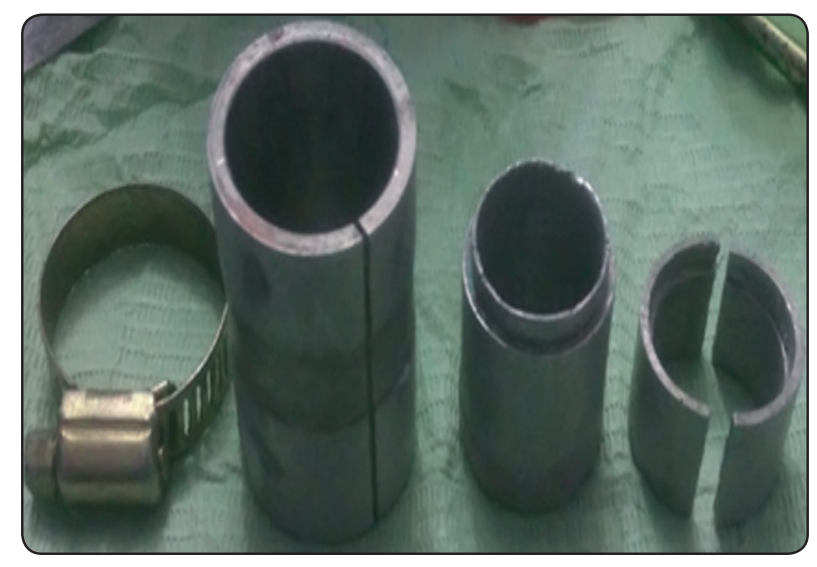

Fig. (1) Metallic Mold. and the mold ${ }^{(25)}$. The surface roughness test of every samples was measured by (Mahr) Marsurf PS1* (Figure 2) Unit of measurement Metric, inch $\mu \mathrm{m}$ $\mathrm{Ra}$ : (Arithmetic mean roughness $\mathrm{Ra}$ ). The average surface roughness of the sampling length ${ }^{(26)}$.

Surface detail reproducibility under both moist and dry conditions on the authority of criteria similar to the American Dental Association specification no. 19. ${ }^{(27)}$. The data were collected, tabulated and analyzed using Student T- and ANOVA test $(\mathrm{P}<0.05)$.

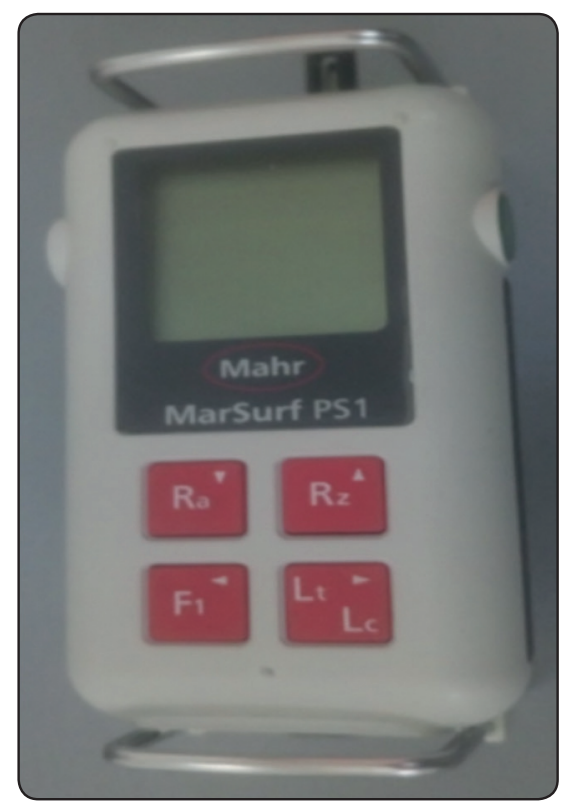

Fig. (2) (Mahr) Marsurf PS1 for measuring the surface roughness.

\section{RESULTS}

The results of this research in control group (without AHD 2000 disinfectant) in (Table 1\& Graph 1) showed that means and standard deviations as regards the surface roughness $(\mathrm{Ra})$ in the different samples according to pouring time using ANOVA test. It stated that the surface roughness of casts obtained at various time periods (one, six, $12 \& 24$ hours not significantly difference.

* Mahr GmbH, Göttingen Germany 
In study group (with AHD 2000 disinfectant) comparison between Means and standard deviations regarding surface roughness $(\mathrm{Ra})$ in the different samples according to casting time were shown in the Table $2 \&$ Graph 2 using ANOVA test. The surface roughness of casts obtained at various time periods (one, six, $12 \& 24$ hours)showed no significant difference In Table 3 \& Graph 3 : Comparison between means and standard deviations of the two studied groups on the report of different periods regarding surface roughness( $\mathrm{Ra})$ using Student t-test. It stated that the surface roughness of casts obtained at various time periods (one, six, $12 \& 24$ hours) showed no significant difference between the control group (without AHD disinfectant) and the test group (with AHD disinfectant)

TABLE (1) The control group (without AHD2000 disinfectant): Comparison between the different samples according to pouring time as regards surface roughness

\begin{tabular}{|c|c|c|c|c|c|c|}
\hline \multirow{2}{*}{ Pouring time } & \multicolumn{3}{|c|}{ control group (without AHD2000 disinfectant) } & \multirow{2}{*}{ F } & \multirow{2}{*}{$\mathbf{p}$} \\
\cline { 2 - 5 } & $\begin{array}{c}\text { After 1hour } \\
(\mathbf{n = 5})\end{array}$ & $\begin{array}{c}\text { After 6hours } \\
(\mathbf{n = 5})\end{array}$ & $\begin{array}{c}\text { After 12hours } \\
(\mathbf{n = 5})\end{array}$ & $\begin{array}{c}\text { After 24hours } \\
(\mathbf{n = 5})\end{array}$ & \multirow{2}{*}{0.620} & \multirow{2}{*}{0.638} \\
\hline Min. - Max. & $1.51-1.59$ & $1.63-1.67$ & $1.48-1.62$ & $1.53-1.74$ & \\
\hline Mean \pm SD. & $1.55 \pm 0.05$ & $1.65 \pm 0.03$ & $1.55 \pm 0.10$ & $1.64 \pm 0.15$ & 1.64 & \\
\hline Median & 1.55 & 1.65 & 1.55 & & \\
\hline
\end{tabular}

$F, p: F$ and $p$ values for ANOVA test

TABLE (2) The study group (with AHD2000 disinfectant): Comparison between the different samples according to pouring time as regards surface roughness

\begin{tabular}{|c|c|c|c|c|c|c|}
\hline \multirow[b]{2}{*}{ Pouring time } & \multicolumn{4}{|c|}{ Study group with AHD 2000} & \multirow[b]{2}{*}{$\mathbf{F}$} & \multirow[b]{2}{*}{$\mathbf{p}$} \\
\hline & $\begin{array}{l}\text { After 1hour } \\
\quad(n=5)\end{array}$ & $\begin{array}{c}\text { After 6hours } \\
(n=5)\end{array}$ & $\begin{array}{l}\text { After 12hours } \\
\qquad(n=5)\end{array}$ & $\begin{array}{c}\text { After 24hours } \\
\quad(n=5)\end{array}$ & & \\
\hline Min. - Max. & $1.36-1.64$ & $2.08-2.70$ & $1.66-2.09$ & $1.60-1.66$ & \multirow{3}{*}{3.815} & \multirow{3}{*}{0.114} \\
\hline Mean \pm SD. & $1.50 \pm 0.20$ & $2.39 \pm 0.43$ & $1.87 \pm 0.30$ & $1.63 \pm 0.04$ & & \\
\hline Median & 1.50 & 2.39 & 1.87 & 1.63 & & \\
\hline
\end{tabular}

F,p: $F$ and $p$ values for ANOVA test

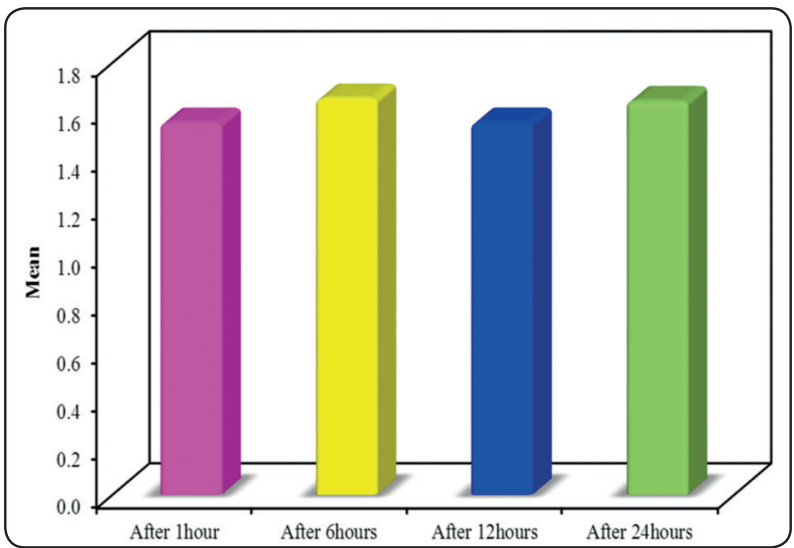

GRAPH (1) Comparison between the different samples according to pouring time in Control group

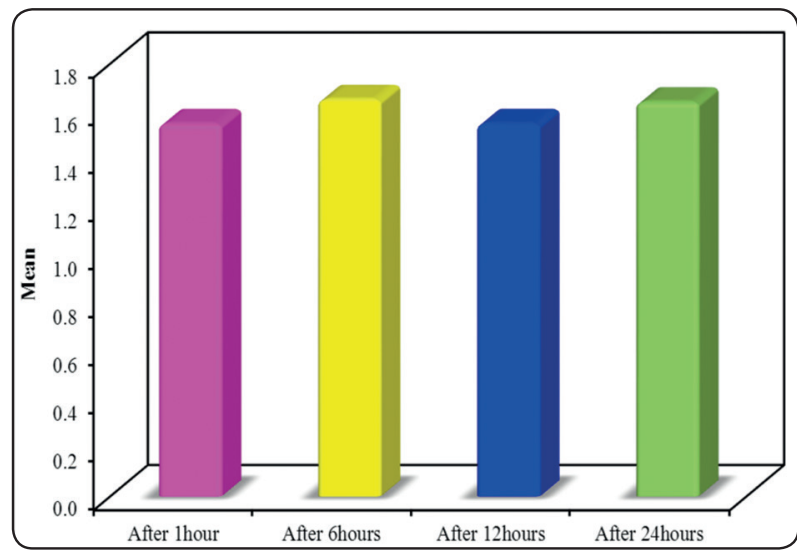

GRAPH (2) Comparison between the different samples according to pouring time in study group 
TABLE (3) Comparison between the control and test group Comparison between the two studied groups according to different periods as regards surface roughness

\begin{tabular}{|c|c|c|c|c|}
\hline Pouring time & $\begin{array}{c}\text { Control group } \\
\text { (without AHD2000 disinfectant) }\end{array}$ & $\begin{array}{l}\text { Study group with } \\
\text { AHD } 2000\end{array}$ & $\mathbf{t}$ & $\mathbf{p}$ \\
\hline After 1hour & $(\mathbf{n}=5)$ & $(n=5)$ & \multirow{4}{*}{0.338} & \multirow{4}{*}{0.767} \\
\hline Min. - Max. & $1.51-1.59$ & $1.36-1.64$ & & \\
\hline Mean \pm SD & $1.55 \pm 0.05$ & $1.50 \pm 0.20$ & & \\
\hline Median & 1.55 & 1.50 & & \\
\hline After 6hours & $(n=5)$ & $(n=5)$ & \multirow{4}{*}{2.407} & \multirow{4}{*}{0.138} \\
\hline Min. - Max. & $1.63-1.67$ & $2.08-2.70$ & & \\
\hline Mean \pm SD & $1.65 \pm 0.03$ & $2.39 \pm 0.43$ & & \\
\hline Median & 1.65 & 2.39 & & \\
\hline After 12hours & $(\mathbf{n}=5)$ & $(n=5)$ & \multirow{4}{*}{1.425} & \multirow{4}{*}{0.290} \\
\hline Min. - Max. & $1.48-1.62$ & $1.66-2.09$ & & \\
\hline Mean \pm SD & $1.55 \pm 0.10$ & $1.87 \pm 0.30$ & & \\
\hline Median & 1.55 & 1.87 & & \\
\hline After 24hours & $(n=5)$ & $(n=5)$ & \multirow{4}{*}{0.050} & \multirow{4}{*}{0.965} \\
\hline Min. - Max. & $1.53-1.74$ & $1.60-1.66$ & & \\
\hline Mean \pm SD & $1.64 \pm 0.15$ & $1.63 \pm 0.04$ & & \\
\hline Median & 1.64 & 1.63 & & \\
\hline
\end{tabular}

$t$, p: t and p values for Student t-test for comparing between the two groups

\section{DISCUSSION}

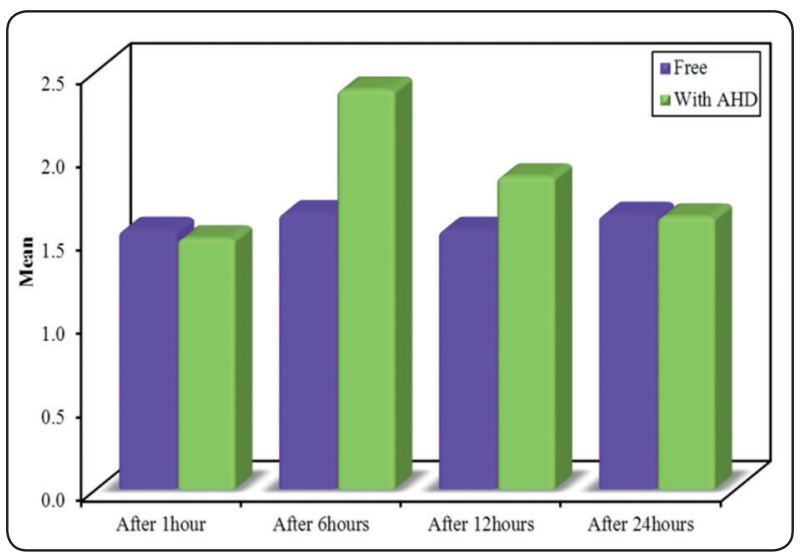

GRAPH (3) Comparison between the two studied groups according to different periods
Irreversible hydrocolloid face problems during laboratory procedures related to contraction and expansion. Success of prosthesis depends on surface details of the casts resulting from the accurate details of the impressions.

Disinfection of the impressions is fundamental for the overriding of cross-infection. The surface of these materials is important to stay unaffected following the procedure of disinfection so as to get high fineness reproduction casts ${ }^{(28)}$. The objective of this research was to assess the effect of disinfection on the surface roughness of stone casts gained from irreversible hydrocolloid (extended-pour) at differ- 
ent periods of pouring \& storage (one, six, 12 and 24 hours) compared with casts of impressions that were not disinfected The objective of this research was to determine whether Hydrogum 5 extendedPour alginates could be disinfected by spraying a commercial disinfectant (AHD 2000) at various time periods of pouring \& storage (one, six, 12 and 24 hours) without affecting surface quality.

Hydrogum 5 which utilize in this study become popular in recent years,we delayed pouring the gypsum to simulate routine clinical procedures by storing the impressions for (one, six, 12 and 24 hours) .This newer material is extended-pour alginate impressions) which their manufacturers claimed that it can be preserved in a good conditions for as long as five day ${ }^{(14)}$.

Recent studies reported that (Hydrogum 5) extended-pour alginate impressions show promising dimensional stable up to 120 hours at consistent temperature and humidity ${ }^{(20,25)}$. However, other study has shown that Hydrogum 5, was dimensionally constant for only $24 \mathrm{~h}^{(29)}$. Disinfection was performed with spraying ready-made commercial disinfectant material: AHD 2000 (Alcohol-based disinfectant).It was used because alcohols are widely used by dentists ${ }^{(30)}$. Due to its bactericidal, fungicidal,tuberculocidal,, and virucidal.

The way of work of alcohols have done by destroying the bacterial proteins, thereby inactivating the microorganisms as long as they inhibit the bacterial growth especially when used in high concentrations versus Streptococcus mutans also, Staphylococcus aureus ${ }^{(31)}$. Badrian $\mathrm{H}$ et al ${ }^{(30)}$ and Hoseini et $\mathrm{al}^{(32)}$ reported that irreversible hydrocolloid could be disinfected by Deconex (alcohol based agent) by spraying method because it was effective toward Staphylococcus aureus and Pseudomonas aeruginosa.

However, what we should consider in reviewing the study results is that they are not entirely comparable with the outcomes of other studies, because of the different types of impression materials as well as different intervals of utilizing of disinfecting agents. The surface roughness $(\mathrm{Ra})$ of casts in control groups obtained from impressions (without disinfection) at various time periods (one, six, 12 \& 24 hours) were not Influenced by storage of the impressions.

This study is agreement with research performed by Guiraldo RD et $\mathrm{al}^{(18)}$ (2015) who evaluate the surface detail of sgypsum casts gained of pouring different irreversible hydrocolloid (Cavex, Hydrogum 5,ColorChange,) extended pour hydrocolloid, or (Jeltrate Plus) conventional hydrocolloid for various storage intervals $1,3 \& 5$ days) with models pouring immediately without storage time.

They stated that, no variation manifested in surface details of stone models made from alginate regardless of differences in storage intervals or alginate used. So, storing alginate impressions for five days prior to pouring did't alter the surface detail replication. Contrary to our results, De Cesero L et $\mathrm{al}^{(33)}$ (2014) concluded that Surface roughness increased significantly with time after pouring, when the Surface roughness was evaluate at 1,24 hours, in addition to 7 days after casting with stone.

In Recent research performed by Kusugal $\mathrm{P}$ et al(2018) ${ }^{(34)}$ evaluated and did a comparison between two newer irreversible hydrocolloid alternatives (AlgiNot FS and Algin-X Ultra FS) with(Kromopan $100)$ extended-pour alginate impression at various time intervals $(1,24, \& 120$ hours). They concluded that irreversible hydrocolloid alternatives were extra accurate in surface detail reproduction in comparison to extended-pour alginate impression after the storage period Study groups where impressions disinfected with AHD showed that the surface roughness $(\mathrm{Ra})$ of casts obtained were not Influenced by the disinfectant solution. The main reason is that AHD disinfectant is a good alcoholic based disinfectant agent, which in the present research could effectively disinfect impressions without effect on the surface roughness of casts . 
The specific feature about this disinfectant is that there no variation manifested in surface roughness (Ra) of the casts after various storage time periods after (one, six, $12 \& 24$ hours). At the time of comparison of the surface roughness $(\mathrm{Ra})$, of the two studied groups (the control group (without AHD disinfectant) and the test group (with AHD disinfectant) it was noted that no changes in the surface roughness $(\mathrm{Ra})$ of casts which obtained at various time periods (one, six, $12 \& 24$ hours).

The standardized impression technique developed for this study may be helpful in obtaining the similar results among the two groups. Also, the results can be because the same environment of the impressions ( stored in plastic bags tightly sealed which produced $100 \%$ humidity ) it is in accordance with a previous study, which concluded that the cast surfaces poured after storage of the impressions in plastic bags tightly sealed were superior to those poured immediately after rinsing ${ }^{(35)}$.

This may due to the lower amount of exudates results from syneresis during impression storage which was reported to decrease the surface roughness of the casts ${ }^{(36)}$. Hiraguchi et $\mathrm{al}^{(36)}$ studied the Influence of two disinfectants, $1 \%$ sodium hypochlorite \& $2 \%$ glutaraldehyde on the resultant models as regards the scratch depth from eleven brands of alginate.

The disinfection method either by immersed or stored in sealed bags next spraying with disinfectants, they results showed immersion of alginate impressions in disinfectants affect scratch depth of the resultant models which varied with the type of alginate. However, that storage of disinfected impressions using the spray method did not affect the scratch depth of produced models.

These results were noticed in the present study, which maybe because of the utilize of spraying technique of the disinfectant material. In a study conducted by Rueggeberg et ${ }^{(37)}$ alto assessed the Influence of disinfection on the surface details of casts produced from conventional and extended-pour alginate immediately and at day 5 after disinfection.

Disinfection by spraying the alginate impressions had to decrease the surface details of the poured stone casts to the identical extent. These results are unlike from our obtained results. Guiraldo RD et al (2012) (26) studied the influence of spraying three disinfectants $(2 \%$ chlorhexidine digluconate, $2 \%$ sodium hypochlorite, or $0.2 \%$ peracetic acid), on the surface detail of the casts produced from (Hydrogum 5, Jeltrate Plus and Cavex Color Change,) alginate materials after $15 \mathrm{~min}$ storage time in comparison with stone casts produced from non-disinfected impressions They concluded that the casts were not influenced by the impression material in addition to disinfectant solutions as regards the surface roughness. These results were noticed for Hydrogum 5 extended-Pour alginates. used in the present study as well.

Jagger et al ${ }^{(38)}$ investigated the influence of disinfectants (Dimenol, Perform-ID, MD-520) on the accuracy of dental stone, poured from three widely utilized impression materials; addition-cured silicone, polyether and alginate. The outcome of the study stated that the different disinfectants had different effects on the impression materials.

It is essential, that a suitable disinfectant is utilize for each kind of impression material. Furthermore, spraying with Dimenol (Alcohol-based disinfectants) not affect the produced casts and the results were the same of the produced casts which left without disinfection These results were detected in the present study as well, which may be because of the spraying technique with AHD (Alcohol-based disinfectants).

\section{CONCLUSION}

Within the limitations of this study:

1. There was no variation manifested in surface roughness of casts reproduced from Hydrogum 
5 extended-Pour alginates .molds regardless of differences in storage time or the utilize of the disinfection or not use.

2. Storing the molds of the newer generation irreversible hydrocolloid in intervals up to 24 hours prior to pouring did not alter the surface roughness of the casts.

3. (AHD 2000) disinfectant was not influencing the surface roughness of the casts .

\section{RECOMMENDATIONS}

1. The use of AHD 2000 as a treatment option for disinfection of Hydrogum 5 extended-Pour alginates. with no significant surface roughness changes of the poured casts.

2. Hydrogum 5 impressions (extended-pour irreversible hydrocolloid material) could be poured after (one, six, $12 \& 24$ hours) of storage, respectively with no significant surface roughness changes of the casts.

3. Impression materials should be mandatorily Disinfected to prevent cross-infection

4. However, further researches are necessary to confirm these findings clinically to estimate the Influence of disinfestation with AHD 2000 on the microbiological identification of oral microorganism, in addition, the dimensional stability of the casts

\section{ACKNOWLEDGMENT}

My sincere thanks and respect to Dr. Mona Hussein Mohy El Din, Professor Of Dental Biomaterials, Faculty of Dentistry, Alexandria University for her valuable guidance, utmost help and effort in every step of this work. This study was conducted in the Dental Biomaterials laboratory facilities of Faculty of Dentistry Alexandria University. I would like to acknowledge the members of the laboratory for their support and aid in the completion of this work.

\section{REFERENCES}

1. Nassar U, Aziz T, Flores-Mir C. Dimensional stability ofirreversible hydrocolloid impression materials as a function of pouring time: a systematic review. J Prosthet Dent. 2011;106:126-33

2. Impressions. In Shillingburg HT, Sather DA, Wilson EL, Cain JR, Mitchell DL, Blanco LJ, Kessler JC. Fundamentals of fixed prosthodontics. 4th ed. Chicago: Quintessence Publishing Co; 2012. p. 291-306.

3. Carvalhal CI, Mello JA, Sobrinho LC, Correr AB, Sinhoreti MA. Dimensional change of elastomeric materials after immersion in disinfectant solutions for different times. J Contemp Dent Pract 2011;12:252-258.

4. Adabo GL, Zanarotti E, Fonseca RG, Cruz CA. Effect of disinfectant agents on dimensional stability of elastomeric impression materials. J Prosthet Dent 1999;81:621-624

5. Leung R.L., Schonfeld S.E. Gypsum casts as a potential source of microbial cross-contamination The Journal of Prosthetic Dentistry, 1983; 49 :210-211

6. Recommended infection-control practices for dentistry, 1993. Centers for Disease Control and Prevention. MMWR Recomm Rep. 1993;42:1-12.

7. Infection control recommendations for the dental office and the dental laboratory. ADA Council on Scientific Affairs and ADA Council on Dental Practice. J Am Dent Assoc. 1996;127:672-80.

8. Lepe X, Johnson GH. Accuracy of polyether and addition silicone after long-term immersion disinfection. J Prosthet Dent. 1997;78:245-9.

9. Amalan A, Ginjupalli K, Upadhya N. Evaluation of properties of irreversible hydrocolloid impression materials mixed with disinfectant liquids. Dent Res J (Isfahan) 2013;10:65-73

10. Chidambaranathan A S, Balasubramanium M. Comprehensive Review and Comparison of the Disinfection Techniques Currently Available in the Literature. Journal of Prosthodontics 2017;00:1-8 by the American College of Prosthodontists

11. Badrian H, Ghasemi E, Khalighinejad N, Hosseini N. The Effect of Three Different Disinfection Materials on Alginate Impression by Spray Method. ISRN Dent. 2012; 2012: 6951 
12. Soares de Moura C D V, de MouraII W L, FrançaIII F M G. et al. Disinfection of irreversible hydrocolloid impressions with sodium hypochlorite steam: Assessment of antimicrobial efficacy. Rev. odonto ciênc. 2010;25:182-187

13. Danish Muzaffar., et al. "A Practical Guide to Use and Methods of Disinfection of Alginate Impression Materials". EC Dental science. 2015; 3: 515-526.

14. Gumus HO' Dincel M, Buyuk KS, Kilinc IH, Bilgin MS, Zortuk M. The effect of pouring time on the dimensional stability of casts made from conventional and extendedpour irreversible hydrocolloids by 3D modelling. J Dent Sci. 2015;10:275-81.

15. 5. Erbe C, Ruf S, Wöstmann B, Balkenhol M. Dimensional stability of contemporary irreversible hydrocolloids: Humidor versus wet tissue storage. J Prosthet Dent. 2012;108:114-22.

16. Rodrigues S B; Augusto C R; Leitune V C B; Samuel S M W; Collares F M. Influence of delayed pouring on irreversible hydrocolloid properties .Braz. oral res 2012 ;26 no.5 São Paulo .

17. Phoenix RD, Cagna DR, DeFreest CF, editors. Stewart's clinical removable partial prosthodontics. 4th ed. Chicago: Quintessence Publishing Co.; 2008. The first diagnostic appointment; pp. 147-8

18. Guiraldo RD, Moreti AF, Martinelli J, Berger SB, Meneghel LL, Caixeta RV, Sinhoreti MA. Influence of alginate impression materials and storage time on surface detail reproduction and dimensional accuracy of stone . Acta Odontol Latinoam. 2015;28: 156-61

19. Sedda M, Casarotto A, Raustia A, Borracchini A. Effect of storage time on the accuracy of casts made from different irreversible hydrocolloids. J Contemp Dent Pract. 2008;9:59-66.

20. Rohanian A, Shabestari G O, Zeighami S, Samadi M J, Shamshiri A R. Effect of Storage Time of Extended-Pour and Conventional Alginate Impressions on Dimensional Accuracy of Casts J Dent (Tehran). 2014; 11: 655-664

21. Mosharraf R, Nasouhian S, Salehi M. Effect of storage time on the dimensional stability of Extended-Pour irreversible hydrocolloid materials. J Isfahan Dent Sch. 2011;7: 246-55.

22. Todd JA, Oesterle LJ, Newman SM, Shellhart WC. Dimensional changes of extended-pour alginate impression materials. Am J Orthod Dentofacial Orthop. 2013;143: 55-63.
23. Abinaya K., Kumar BM, Ahila S C .Evaluation of Surface Quality of Silicone Impression Materials after Disinfection with Ozone Water: An In vitro Study Contemp Clin Dent. 2018; 9: 60-64

24. Kusugal PP, Chourasiya R S, Ruttonji Z, Astagi P, Nayak A K, Patil A. Surface Detail Reproduction and Dimensional Stability of Contemporary Irreversible Hydrocolloid Alternatives after Immediate and Delayed Pouring. Contemp Clin Dent. 2018; 9: 20-25

25. Aalaei S, Ganj-Khanloo, R, Gholami F. Effect of Storage Period on Dimensional Stability of Alginplus and Hydrogum 5 . J Dent (Tehran). 2017; 14: 31-39

26. Guiraldo R D, Borsato T T,Berger s B, Gonini-Jr M L, Sinhoreti, M Co. Surface Detail Reproduction and Dimensional Accuracy of Stone Models: Influence of Disinfectant Solutions and Alginate Impression Materials Braz Dent J 2012; 23: 417-421.

27. American National Standards Institute/American Dental Association: Specification No. 19 for dental elastomeric impression materials. J Am Dent Assoc. 1977;94:733-41;addendum 1982;105:686

28. Hemalatha.R \& Dhanraj G .Disinfection of Dental Impression- A Current Overview.Res. 2016; 8: 661-664

29. Jiang T, Lee SM, Hou Y, Chang X, Hwang HS. Evaluation of digital dental models obtained from dental cone-beam computed tomography scan of alginate impressions. Korean J Orthod. 2016;46:129-36.

30. Badrian H, Ghasemi E, Khalighinejad, N, Hosseini N. The Effect of Three Different Disinfection Materials on Alginate Impression by Spray Method ISRN Dent. 2012; 2012: 695151

31. Peters BM, Ward RM, Rane HS, et al. Efficacy of ethanol against Candida albicans and Staphylococcus aureus poly microbial films. Antimicrob Agents Chemother 2013;57:7482

32. Hoseini SA, Shahcheraghi F, Ghaemmaghami A. Evaluation of the clinical efficacy of quaternary ammonium components (QAC) as surface disinfectant. Journal of Dentistry of Tehran University of Medical Sciences. 2006;3:190-194.

33. De Cesero L, Mota EG, Burnett LH Jr, Spohr AM. The influence of postpouring time on the roughness, compressive strength, and diametric tensile strength of dental stone. J Prosthet Dent 2014;112:1573-7. 
34. Kusugal P, Chourasiya RS, Ruttonji Z, Astagi P, Nayak AK, Patil A. Surface Detail Reproduction and Dimensional Stability of Contemporary Irreversible Hydrocolloid Alternatives after Immediate and Delayed Pouring Contemp Clin Dent. 2018;9:20-25

35. Tan HK, Hooper PM, Buttar IA, Wolfaardt JF. Effects of disinfecting irreversible hydrocolloid impressions on the resultant gypsum casts: Part III - Dimensional changes. J Prosthet Dent 1993; 70:532-537.

36. Hiraguchi H1, Nakagawa H, Wakashima M, Miyanaga K, Saigo M, Nishiyama M. Effects of disinfecting alginate impressions on the scratch hardness of stone models. Dent Mater J 2006; 25:172-176.

37. Rueggeberg FA, Beall FE, Kelly MT, Schuster GS. Sodium hypochlorite disinfection of irreversible hydrocolloid impression material. The Journal of Prosthetic Dentistry. 1992;67: 628-631

38. Jagger DC, Al Jabra O, Harrison A, Vowles RW, McNally L. The effect of a range of disinfectants on the dimensional accuracy of some impression materials. Eur J Prosthodont Restor Dent. 2004;12:154-60 